\title{
Mystery Case: Eccentric target sign in CNS toxoplasmosis
}

\author{
A rare presentation of Good syndrome
}

Yung-Chun Cheng, MD, Jiann-Horng Yeh, MD, Hsu-Ling Yeh, MD, Li-Ming Lien, MD, PhD, Wei-Yu Chen, MD, Chen-Yu Hsiao, MD, Yong-Hui Liu, MD, Ching-Lin Chen, MD, Shih-Ying Chen, MD, and Chi-leong Lau, MD, $\operatorname{MSc}(\operatorname{Res}), \mathrm{MSc}$

Neurology ${ }^{\circledR}$ 2019;92:e516-e518. doi:10.1212/WNL.0000000000006862

A 61-year-old man with myasthenia gravis who previously underwent post-thymectomy radiotherapy for a metastatic thymoma presented with altered mental status. Examination revealed papilledema and frontoexecutive dysfunction.

Brain MRI disclosed rim-enhancing lesions with the eccentric target sign pathognomonic for neurotoxoplasmosis, ${ }^{1}$ supported by magnetic resonance spectroscopy (figure 1). Brain biopsy confirmed the presence of Toxoplasma gondii tachyzoites (figure 2). Absent B cells, low $\mathrm{CD}^{+}$and $\mathrm{CD}^{+}$counts, hypogammaglobulinemia, and a HIV-negative status led to the diagnosis of Good syndrome. Treatment with pyrimethamine-clindamycin resulted in mild improvement.

Neurotoxoplasmosis is a rare opportunistic infection in HIV-negative patients with thymoma. ${ }^{2}$ Early recognition and prompt immunologic workup are warranted.

\section{Mystery Case Responses: A 61-year-old man with altered mental status}

The Mystery Case series was initiated by the Neurology ${ }^{\circledR}$ Resident \& Fellow Section to develop the clinical reasoning skills of trainees. Residency programs, medical student preceptors, and individuals were invited to use this Mystery Case as an educational tool. Responses to multiple choice questions formulated using this case were solicited through a group email sent to the American Academy of Neurology Consortium of Neurology Residents and Fellows and through social media. We received 299 responses. The majority of respondents (68\%) had been in practice for 1-4 years; $64 \%$ were residents or fellows while $27 \%$ were faculty/board-certified physicians; the remainder were medical students or advanced practice providers. A total of $69 \%$ resided outside the United States. A wide range of practice settings was represented.

When shown a brief vignette about the patient's clinical presentation followed by representative MRI brain sections (figure 1, A-F), $85 \%$ of respondents correctly identified the left frontal lobe ring-enhancing lesions, but only $7 \%$ also correctly identified the smaller right parietal lobe ring-enhancing lesion. A total of $60 \%$ recognized the associated vasogenic edema and 30\% also recognized the peripheral diffusion restriction. Upon then being asked to select their top 5 differential diagnoses, the most popular choices were as follows: cerebral metastases (75\%), tubercular or bacterial abscesses (70\%), primary CNS lymphoma (57\%), and fungal abscesses (55\%), followed by a close race for fifth place between glioblastoma multiforme (53\%) and toxoplasmosis (51\%). In this case, toxoplasmosis would be a preferred response over glioblastoma; whereas neurotoxoplasmosis typically manifests as

\section{Correspondence}

Dr. Lau

chiieong.lau@ndcn.oxon.org

\section{MORE ONLINE}

Survey and results

NPub.org/mc9205

\section{$\rightarrow$ Teaching slides}

links.lww.com/WNL/A797

From the Department of Neurology (Y.-C.C., J.-H.Y., H.-L.Y., L.-M.L., C.-I.L.), Division of Infectious Diseases (W.-Y.C.), Department of Diagnostic Radiology (C.-Y.H.), and Department of Neurosurgery (Y.-H.L., C.-L.C., S.-Y.C.), Shin Kong Wu Ho-Su Memorial Hospital; College of Medicine (J.-H.Y., C.-I.L.), Fu-Jen Catholic University; School of Medicine, College of Medicine (L.-M.L.), Taipei Medical University, Taiwan; and Institute of Cognitive Neuroscience (C.-I.L.), University College London, UK.

Go to Neurology.org/N for full disclosures. Funding information and disclosures deemed relevant by the authors, if any, are provided at the end of the article. 


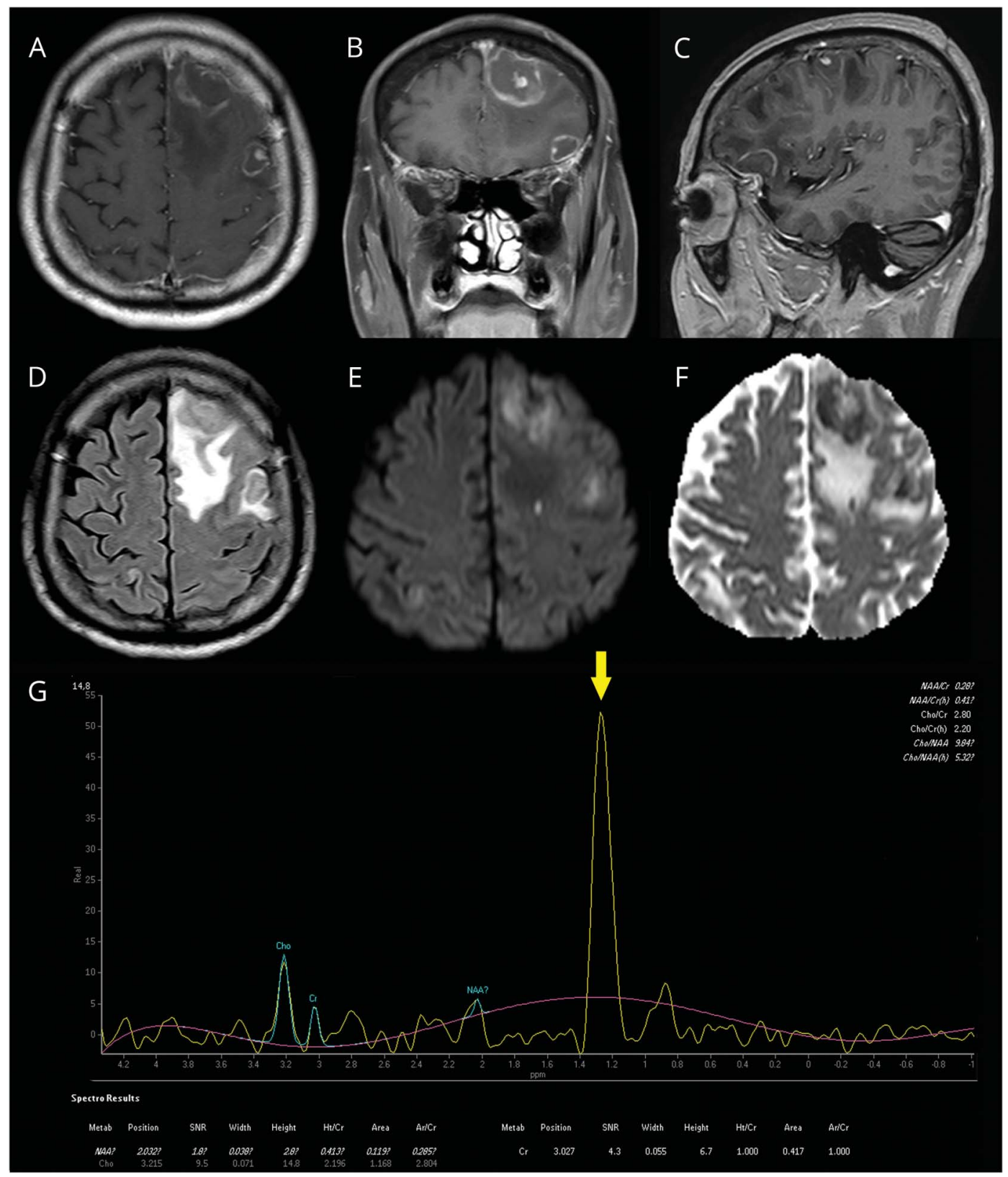

(A) Axial, (B) coronal, and (C) sagittal contrast-enhanced MRI reveals multiple ring-enhancing lesions with the eccentric target sign pathognomonic for neurotoxoplasmosis, with (D) vasogenic edema and (E, F) corresponding peripheral diffusion restriction. (G) Magnetic resonance spectroscopy shows high lactate peak, diminished $\mathrm{N}$-acetylaspartate, and choline metabolites.

multiple lesions, with a characteristic eccentric target sig$\mathrm{n}$ as seen in these images, ${ }^{1}$ multicentric glioblastomaswith multiple discrete contrast-enhancing lesions not linked by $\mathrm{T} 2$ /fluid-attenuated inversion recovery signal abnormality-are uncommon. ${ }^{2}$

Upon then being shown the brain biopsy specimen (figure 2) and asked to select their final diagnosis, $32 \%$ of respondents correctly chose toxoplasmosis. Other popular choices included tubercular or bacterial abscesses (16\%), fungal abscesses (14\%), and primary CNS lymphoma (12\%).
However, none of these alternative diagnoses would be expected to demonstrate the pathologic finding of extracellular crescent-shaped tachyzoites with prominent centrally placed nuclei, which in this case confirms infection with Toxoplasma gondii.

This case complements a recent Mystery Case in addressing the differential diagnosis for ring-enhancing lesions, ${ }^{3}$ in addition to reviewing the neuroimaging and neuropathologic features of an important neuroinfectious disease. ${ }^{4}$ 
Figure 2 Histopathologic examination of the brain biopsy specimen

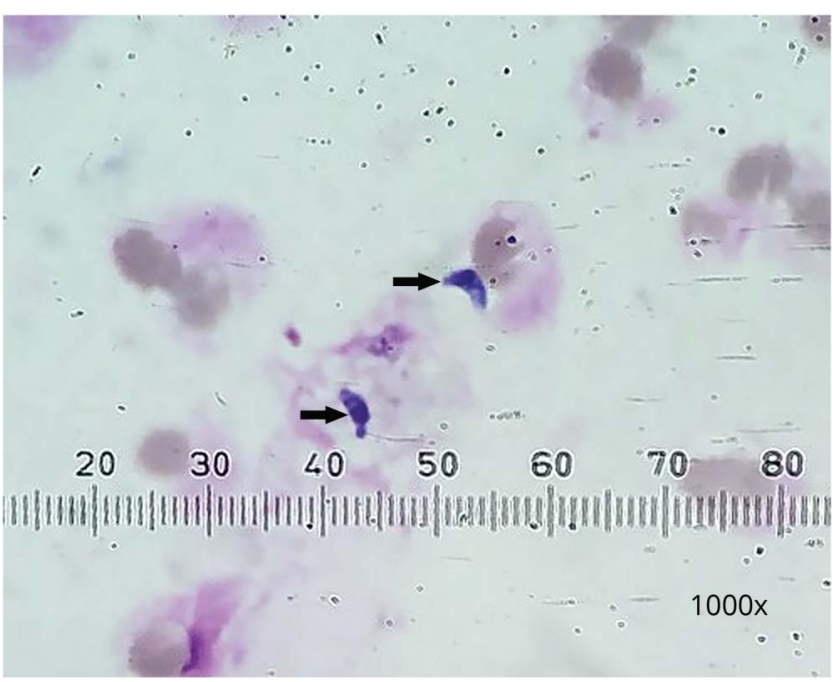

A smear of brain biopsy at $\times 1,000$ magnification shows 2 extracellular crescent-shaped Toxoplasma gondii tachyzoites with prominent, centrally placed nuclei.

\section{References}

1. Kumar GG, Mahadevan A, Guruprasad GS, et al. Eccentric target sign in cerebral toxoplasmosis: neuropathological correlate to the imaging feature. J Magn Reson Imaging 2010;31:1469-1472.
2. Kelesidis T, Yang O. Good's syndrome remains a mystery after 55 years: a systematic review of the scientific evidence. Clin Immunol 2010;135:347-363.

\section{Author contributions}

Y.-C. Cheng: study design, data collection, drafting the manuscript. J.-H. Yeh: study supervision, revising the manuscript. H.-L. Yeh: study design, data collection. L.-M. Lien: study design, data collection. W.-Y. Chen: study design, data collection. C.-Y. Hsiao: study design, data collection. Y.-H. Liu: study design, data collection. C.-L. Chen: study design, data collection. S.-Y. Chen: study design, data collection. C.-I. Lau: study design, data collection, drafting and revising the manuscript.

\section{Study funding}

No targeted funding reported.

\section{Disclosure}

The authors report no disclosures relevant to the manuscript. Go to Neurology.org/N for full disclosures.

\section{References}

1. Kumar GG, Mahadevan A, Guruprasad AS, et al. Eccentric target sign in cerebral toxoplasmosis: neuropathological correlate to the imaging feature. J Magn Reson Imaging 2010;31:1469-1472.

2. Hassaneen $\mathrm{W}$, Levine NB, Suki D, et al. Multiple craniotomies in the management of multifocal and multicentric glioblastoma. J Neurosurg 2011;114:576-584.

3. Kim SU, Choi JY, Lee YH, et al. Mystery case: rim enhancement in cerebral aneurysm: an atypical feature. Neurology 2016;86:e35-e36.

4. Pruitt AA. Central nervous system infections complicating immunosuppression and transplantation. Continuum (Minneap Minn) 2018;24:1370-1396. 


\section{Neurology}

\section{Mystery Case: Eccentric target sign in CNS toxoplasmosis: A rare presentation of Good syndrome \\ Yung-Chun Cheng, Jiann-Horng Yeh, Hsu-Ling Yeh, et al. \\ Neurology 2019;92;e516-e518 \\ DOI 10.1212/WNL.0000000000006862}

This information is current as of January 28, 2019

\section{Updated Information \& Services}

References

Subspecialty Collections

Permissions \& Licensing

Reprints including high resolution figures, can be found at: http://n.neurology.org/content/92/5/e516.full

This article cites 6 articles, 1 of which you can access for free at: http://n.neurology.org/content/92/5/e516.full\#ref-list-1

This article, along with others on similar topics, appears in the following collection(s):

\section{MRI}

http://n.neurology.org/cgi/collection/mri

Myasthenia

http://n.neurology.org/cgi/collection/myasthenia

Parasitic infections

http://n.neurology.org/cgi/collection/parasitic_infections

Information about reproducing this article in parts (figures,tables) or in its entirety can be found online at:

http://www.neurology.org/about/about_the_journal\#permissions

Information about ordering reprints can be found online:

http://n.neurology.org/subscribers/advertise

Neurology ${ }^{\circledR}$ is the official journal of the American Academy of Neurology. Published continuously since 1951, it is now a weekly with 48 issues per year. Copyright @ 2019 American Academy of Neurology. All rights reserved. Print ISSN: 0028-3878. Online ISSN: 1526-632X.

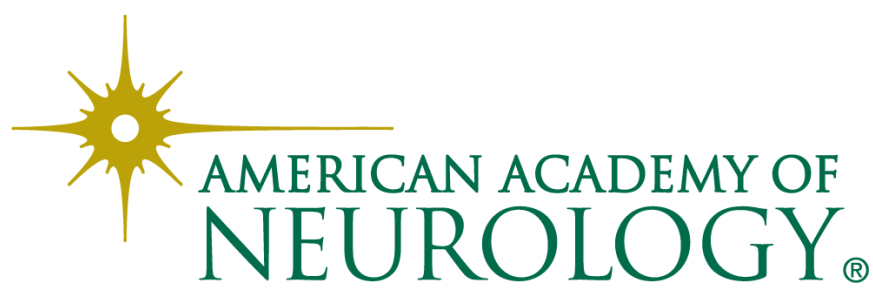

